\title{
Financial Health Affects Medical Outcomes; the Case of Some Mission Hospitals in Ghana
}

\author{
Ebenezer Kenneth Abban \\ Healthcare Administration, Texila American University, Akwatia, Ghana
}

\begin{abstract}
Health financing is a major pillar in the delivery system. Health care services are financed by governments and non-governmental organizations, all for the ultimate objective of ensuring the delivery of care. Health facilities have the onus to create the enabling environment to ensure that care is in continuum and at least efforts are made at the provision of quality care. The financial healthiness of hospitals certainly affects medical outcomes since it takes money to render every service in the healthcare industry. This study worked on the assumption that financial health affects medical outcomes, and the data has proven to be true that there was a positive/significant correlation $(p<0.0001 *)$ of the topic.
\end{abstract}

Keywords: Clinical Indicators, Financial Health, Health Financing, Hospitals, Healthcare, Medical Outcomes.

\section{Introduction}

Financial management is arguably one major component in the delivery of all services [1], especially in health services delivery to meet the expectations of patients. The exercise of power plays a crucial role in the management of healthcare organizations [2]. Given that power influences the administration of health service delivery, it is the opinion of the researcher that strong leadership towards the right objectives in the delivery of quality health services can significantly position the financial health of hospitals to positively affect medical outcomes.

"According to the 2009 World Health Organization (WHO) National Health Accounts, 47 percent of total health spending in Ghana is private (37 percent paid out of pocket and 10 percent paid by private insurance and other private risk-pooling mechanisms). Of the 53 percent public spending share, the NHIS accounts for some 30 percent of public spending on health and 16 percent of total health spending. Depending on how it is measured, public spending on health in Ghana is either slightly above or about the same as global income comparators. Depending on how it is measured, out-of-pocket spending (a gross measure of financial protection) in Ghana is higher than or about the same as global income comparators but twice the threshold recommended by the WHO" [3].

Medical outcomes are largely dependent on the availability of adequate funds. Availability of funds in healthcare delivery is very essential at all times. Therefore, health financing on the back of good leadership [4] could be described as the lifeline to the very survival of the healthcare industry, especially, in an era where a study by John Hopkins found that disruption to the health systems caused by Covid-19 could result in an additional 1.1 million child deaths and 56,700 maternal deaths in low- and middleincome countries [5]. Concerns such as the ability to raise funds for health; reducing financial barriers to access healthcare through prepayment and subsequent pooling of funds in preference to direct out-of-pocket payments by patients and allocating or using funds in a way that promotes efficiency and equity in health 
financing determine the very existence of healthcare service delivery in any country [6]. Health financing, and the subsequent medical outcomes, have even become more relevant and crucial today in the world more than ever before because governments across the globe are making and require every effort, on a continuous basis, towards the achievement of the Sustainable Development Goals (SDGs) of 2030, and in particular SDG 3 - "To ensure healthy lives and promote well-being for all at all ages."[7]. Health financing invariably is basic to the very survival of the operations of healthcare delivery systems [8].

It refers to the "function of a health system concerned with the mobilization, accumulation, and allocation of money to cover the health needs of the people, individually and collectively, in the health system the purpose of health financing is to make funding available, as well as to set the right financial incentives to providers, to ensure that all individuals have access to effective public health and personal health care" [9].

Funding for the delivery of healthcare ultimately aims at yielding better medical outcomes. In the estimation of the World Health Organization [10], measuring progress towards universal health coverage for example, shall require strong country health financing systems that can provide equitable access to quality health services. Thus, many healthcare providers often present quarterly, semi-annually, and annual performance reviews on their performances. Invariably, the objective of health financing, as generally expressed by scholars of the industry, is not only to put systems to raise adequate funding for healthcare delivery but more importantly, to create an equitable system of payment where patients are able to access unimpeded health services without the risk of not having access to healthcare due to financial difficulties. Therefore, health financing could largely imply systems to raise sufficient funds for the delivery of healthcare and to dispense financial risk defense for the general population.
These objectives will be easier to obtain if the available funds are used efficiently - so efficiency in a resource is usually taken as a third objective. As a result, according to World Health Organization, the financing system is often divided conceptually into three inter-related functions - revenue collection, fund pooling, and purchasing/provision of services. Before focusing on measurement strategies and indicators for these functions, it is important to understand the key components of each of them. In the World Health Organization's assessments of member country's health financing regime for 2015, this assertion was made.

"Most low-income and many middle-income countries, revenue collection derives from a mix of domestic and external sources. Despite the substantial increases in external assistance for health since 2000, the resources available are still insufficient in most low-income settings to assure universal coverage with even a very basic set of needed interventions. This is not the place to debate exactly how much is needed, but adjustment of Commission on Macroeconomics and Health estimates of the cost of a core package to current prices reveals a need for around US\$40 per person per year. This is an underestimate for many reasons, but even then, almost a third of the 193 member countries of WHO did not yet have access to even this level of funding in 2005, while 33 spend less than $\$ 25$ per person each year despite increased external inflows. An ideal indicator of this part of the financing system would need to capture the amount and the adequacy of the funds that are raised."

Ghana is a member of the World Health Organization, and like other sub-Saharan African countries, such as Kenya, Nigeria, Tanzania, and Uganda, different forms of health insurance were observed. These health insurances are primarily community-based. No doubt, the NHIS has made care accessible and affordable in Ghana, and some groups of people such as the aged, children, and pregnant women are given immunity against premium payment. 
This has assisted to remove some amount of financing barriers to healthcare. People who are registered in the scheme use healthcare services more than those who are not insured. Though the NHIS increased access to healthcare, this access is far from universal, as it demands premium payment before one can access healthcare thus, still impeding unimpeded access to care. Many studies reported varying proportions of the population who are not covered by the scheme; a World Bank study, for example, reported that only $40 \%$ of the Ghanaian population were enrolled in the scheme by 2013 [11]. A health financing regime that totally insolates the population from financial difficulty in accessing an equitable healthcare delivery system may still be far from achievable in Ghana.

This requires resilient and well-managed financial systems at the facility level so that patient's need, at least those who can access care, are met on a visit. Purchasing of medical consumables, payment of salaries of staff, and indeed maintenance of general operation systems of the hospital all require the use of money. Health financial eventually aims at a healthy financial base for quality delivery of health services. Thus, the financial health of hospitals is largely related to medical outcomes because service delivery is closely knit to funding capacity. Consequently, the researcher sought to test this hypothesis:

Ho (null): $\mu \mathrm{A}-\mu \mathrm{c}=\mathrm{O}$ Financial health does not influence medical outcomes of hospital.

Ha (alter): $\mu \mathrm{A}-\mu \mathrm{c}=\varnothing$ Financial health does influence medical outcomes of hospital.

\section{Methodology}

All the seven mission hospitals in that part of Ghana were selected. A targeted group of three each of health information officers and senior accountants were engaged in structured interviews. This was based on the last three year's (2018 - 2020) financial position statements and ten year's of clinical indicators on specific medical outcomes. While simple random sampling was employed for the other selected health workers based on the number of respondents for each facility. Each hospital had a total of the designated number as shown in the sample size table (Refer Table 1).

These people were engaged through field agents at the 7 hospitals to ensure that the responses would be true and objective reflections of the real situations on the ground. Thus, to avoid unnecessary biases in the responses so that the ultimate result of the study could ignite the enabling discussions needed to open new avenues and add to the stock of knowledge. Following from Bryman and Bell (2007), the researcher solemnly declared adherence to the standards as required under ethical considerations of research work. And ethical clearance was sought from the Institutional Review Board of the Christian Health Association of Ghana PIN: (CHAGIRB02022021).

\section{Study Type}

A cross sectional study research design. It employed trend analysis of data available and which were collected on the field.

\section{Population and Sample Size}

The total population of the study was 2853 . And the formula below was used to select a total of 1350 as the sample size $(n)=N /\left[1+N\left(e^{2}\right)\right]$. Where; $\mathrm{n}=$ Sample Size, $\mathrm{N}=$ Total population, $\mathrm{e}=$ margin of error $(5 \%$ or 0.05$)$ with confidence level of $95 \%$. Refer Table 1. 
Table 1. Sample size

\begin{tabular}{|l|l|l|}
\hline Facilities & Population & Sample size (n) \\
\hline 1 & 687 & 253 \\
\hline 2 & 484 & 219 \\
\hline 3 & 620 & 243 \\
\hline 4 & 286 & 167 \\
\hline 5 & 218 & 141 \\
\hline 6 & 238 & 149 \\
\hline 7 & 320 & 178 \\
\hline Total & 2853 & 1350 \\
\hline
\end{tabular}

Source: Ryan, (2013)

\section{Data Collection and Tools}

The investigator utilized structured interviews and administration of questionnaires in a survey to collect and gathered the required data. Data were entered into open-source software - Epidata. The data were later exported to 'Stata 15' software for analysis. In the interviews, participants of the study were asked questions bothered on the financial health and medical outcomes of the hospitals over a period of three years and ten years. Questions on the financial health of the hospitals based on the financial position statements of the hospitals for the previous three years $(2018$ - 2020) were asked, and financial ratios were calculated in a word document table. The data on annual clinical indicators for ten years $(2011-2020)$ were entered onto a simple excel spreadsheet to determine the averages of the medical outcomes. Additionally, respondents of the questionnaire were made to answer 5-point Likert scale questions on the financial performance and medical outcomes of the hospitals.

\section{Data Analysis}

Financial ratios were used, and averages were applied in each of the parameters in assessing the financial health of the facilities. Particular reference was made to profitability, liquidity, and operating efficiency. This was based on the assessment of the audited financial position statements of the mission hospitals for a threeyear period (2018-2020). Again, utilizing the remits set by Alanna-Moriarty [12], trend analysis, for ten years, was performed on the rate of admissions, rate of OPD attendance, and percentage of OPD insured using a simple excel spreadsheet. Emphasis was laid on the previous three years $(2018-2020)$ at the results column to correspond with the effect of financial health on medical outcomes as indicated by the topic. Additionally, 'Stata 15' was used in the analysis of the data gathered from the responses to the questionnaire. The data was analyzed in descriptive, regression, correlation, and hypothesis testing to establish the veracity or otherwise of the influence of the independent variable on the medical outcomes of mission hospitals.

\section{Variables Measurement}

Refer Table 2.

Table 2. Variables Measurement

\begin{tabular}{|l|l|}
\hline Table of Variables Measurement \\
\hline Dependent variable & Medical outcomes of hospital \\
\hline Independent variables & Financial health \\
\hline
\end{tabular}

Source: Field work, 2021 


\section{Results and Discussions}

Table 3 below shows an unadjusted linear regression analysis. The analysis revealed that there is strong evidence of a statistically significant relationship between financial health and medical outcomes of the 7 mission hospitals. The outcome of the analysis indicated that a unit change in the perceived mean score of the financial health of mission hospitals will increase the perceived mean score of medical outcomes by 0.49 times with $p$-value $<0.0001$; 95\%CI [0.45-0.54].

The R-squared of $25.3 \%$ shows that financial health accounts for $25.3 \%$ of the variations in the model. The outcome of the analysis proves my hypothesis that financial health influences medical outcomes in mission hospitals was true. The financial health of mission hospitals has a positive effect on medical outcomes.

Table 3. Simple Linear Regression showing the Impact of Financial Health on Medical Outcomes of Mission Hospitals

\begin{tabular}{|l|l|l|l|l|}
\hline Covariate & Coefficient & Standard Error & $\boldsymbol{p}$-value & 95\% CI \\
\hline Financial health & 0.49 & 0.02 & $<0.0001 *$ & {$[0.45-0.54]$} \\
\hline
\end{tabular}

Statistically significant at $\mathrm{p}<0.0001 *$

CI - Confidence Interval

Adjusted R-squared $=0.2530$

Hypothesis

Reject $\mathrm{H}_{0}$ and conclude on $\mathrm{H}_{1}$

The investigator relied on the averages gathered on the year to year ending financial statements of the selected facilities in calculating the profitability of the hospitals. Financial ratios, i.e., return on capital; net profit margin, and asset turnover ratios, were utilized. Generally, return on capital employed measures the extent of a company's profitability. If the ratio was rising, it meant that the capital employed of the company was generating enough profits. From table 3, the average of this ratio increased from $2.79 \%$ in 2018 to $7.32 \%$ in 2019 . It, however reduced by $5.25 \%$ in 2020 .

Although in 2020 it decreased, it was still better than that of 2018. And this meant that the hospitals were profitable under the period of review. For every Cedi of Capital Employed by the Hospitals in 2020, 5.25\% of it was generated into operating profit or surplus. Thus, to earn every Cedi, the hospital needed to employ GH $\varnothing 19.05$ worth of Capital. Net Profit margin shows the net profit expressed as a percentage of sales /turnover/revenue. When this ratio is rising, it is an indication that operating expenses are effectively controlled and that the company earns a meaningful profit from its sales. The Net
Profit Margin increased from $1.72 \%$ in 2018 to $4.59 \%$ in 2019 but decreased to $3.10 \%$ in 2020 . A $3.10 \%$ Margin is an indication that the Hospitals earn, on average, 3.10 pesewas for every Cedi it collected. Asset Turnover measures how well the assets of a business are being used to generate sales. This explains more about the efficiency of the assets. The assets turnover ratio, however decreased from 1.62 times in 2018 to 1.59 times in 2019 before rising to 1.69 times in 2020.

The Liquidity position of the hospitals was determined by assessing the current and quick or acid test ratios. The current ratio shows the hospitals' ability to pay short-term obligations or those due within one year. It is generally asserted that the best relationship between current assets and current liabilities should be 2:1.

The current ratio has been rising over the years. For every GH $₫ 1.00$, the hospitals' owed in current liabilities, they had on average $\mathrm{GH} ф 2.35$ to pay in 2018; $\mathrm{GH} ф 2.48$ to pay in 2019 , and $\mathrm{GH} \phi 3.41$ to pay in 2020. Quick ratio or the acid test ratio compares the Hospitals' most short-term assets to its most short-term 
liabilities to see if it has enough cash to buy off the immediate liabilities.

This ratio shows the relationship between liquid assets and current liabilities. Generally, a ratio of $1: 1$ is acceptable. The quick ratio has been increasing over the period 1.73:1 in 2018, 1.98:1 in 2019, and 2.66:1 in 2020. In calculating the operation efficiency of the hospitals, the receivables days ratio which focuses on the time it takes for debtors to settle their bills and shows whether debtors are allowed excessive credit period, which was 83.56 days in 2018, 87.09 days in 2019, and 74.62 days in 2020; payables days ratio which gives insight into whether a business is taking full advantage of trade credit available to it or not stood at 237.98 day in 2018 , 242.81 days in 2019, and 152.45 days in 2020; the average inventory turnover period which depicts the rate at which the hospitals sold and replaced their stock of goods during a particular period which was 176.09 days in $2018,128.26$ days in 2019 and 115.18 days in 2020; and the rate of inventory turnover, a measurement of the number of times inventory was sold or used in a given time period, usually per year - the rate rising shows how well the hospitals had been converting their inventory into sales, the rate of inventory turnover for 2018 was 2.07 times then increased to 2.85times in 2019 and in 2020 the rate was 3.17 times, were all analyzed. The ratios, when put together, helped to determine the cash conversion cycle, which measures how much time the hospitals took to sell their inventory, how much time they took to collect receivables, and how much time they took to pay their bills. The cash conversion cycle of the hospitals had been reducing from 21.46 in 2018 to -27.46 in 2019 , then to -4.23 in 2020 . The negative cash conversion cycle meant that it took the hospitals a longer time to pay suppliers/creditors than it took them to sell their inventory and get reimbursed by their debtors. This implies that the operations of the hospitals were financed by suppliers. Therefore, the hospitals did not need operating cash to grow.

These financial metrics reflected on the medical outcomes of the hospitals over the period under discussion. Utilizing clinical indicators on a trend analysis basis, over a period of ten years and five years, in some cases, i.e., a trend of admissions, a trend of OPD attendance, and trend of percentage of OPD insured, the data spoke to the hypothesis as true.

The trend of admissions, generally, is a measure of hospital revenue mobilization. Inpatient services pay better [13] than outpatient service. Although in recent times, however, the trend is changing. All things being equal, when admissions grow in percentages or numbers, it also means that revenue could rise. Bed occupancy rate reels on inpatients services. The latter, just like the former, is also acutely observed as a measure of the medical outcome. Globally, it is evident from available data that, due to the novel COVID-19, total hospital admissions dropped by $8.5 \%$ of the total expected admission in 2020.

Thus, "total admissions dropped to $69.2 \%$ of predicted admissions during the week ending April 4, 2020 - the lowest point in the year before rising again and staying at or above $90 \%$ since June 2020" [14].

This was not different from the trend in Ghana as hospitalization generally went down in 2020 [15]. Among other reasons, people simply refused to visit hospitals for fear of contracting the virus. Nevertheless, even though from figure 1 , it is observed that total admissions went down in the mission hospitals by 4 percentage points from the previous year, the figure was better comparing with $8.5 \%$ as was reported elsewhere, and extremely ahead of the years 2017 and 2018. 

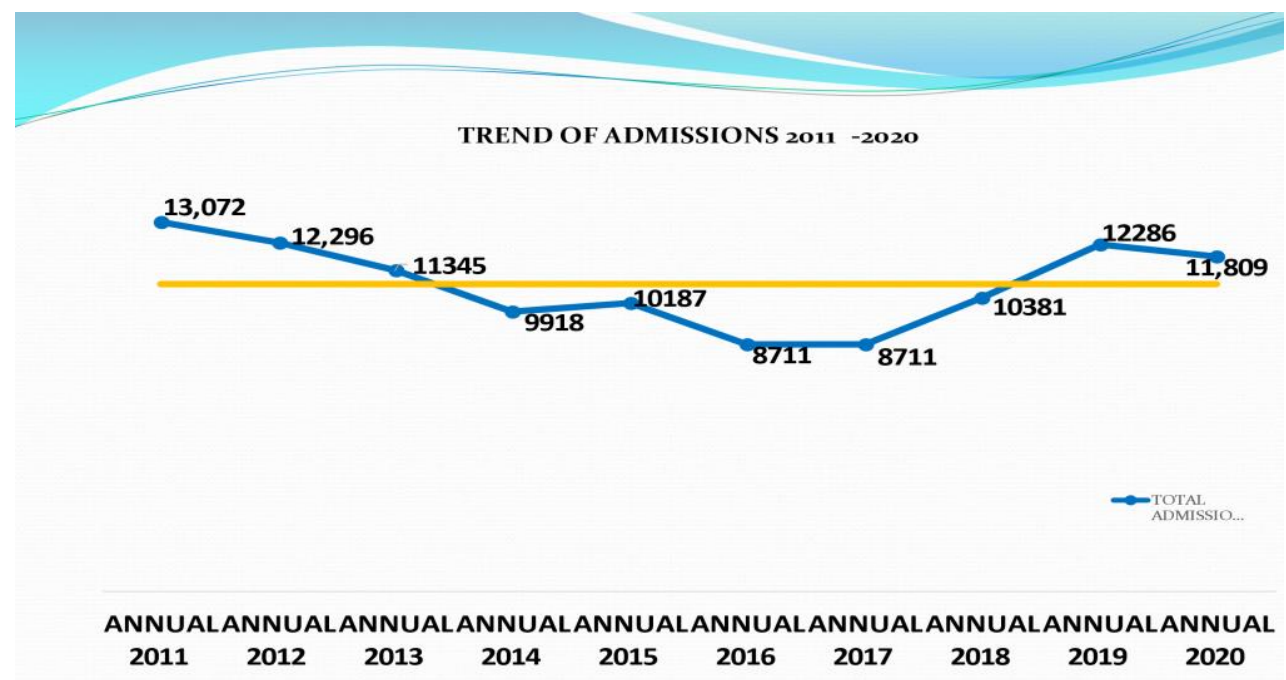

Source: Fieldwork, 2021

Figure 1. Trend of Admissions

OPD attendance as a measure of medical outcomes was good. Wendy Gerhardt \& Ankit Arora share the view that, unlike previous times when patients would spend more days in the hospital after, for example, surgical procedure, today, many patients have procedures in ambulatory centers and go home the same day. The shift lays focus now, more than ever, on outpatient care, and this largely is made possible by the advances in clinical technology. There is no doubt that the rise in OPD attendance is a measure of revenue increases. Although, according to Akudjedy, hospital's out-patient attendance reduced by almost $50 \%$ with attendant loss of revenue in 2020, the story was different albeit marginally. The OPD attendance at the mission hospitals saw an increase of 0.33 percent on the contrary. Clearly, this was a measure of good medical outcome (Figure 2).
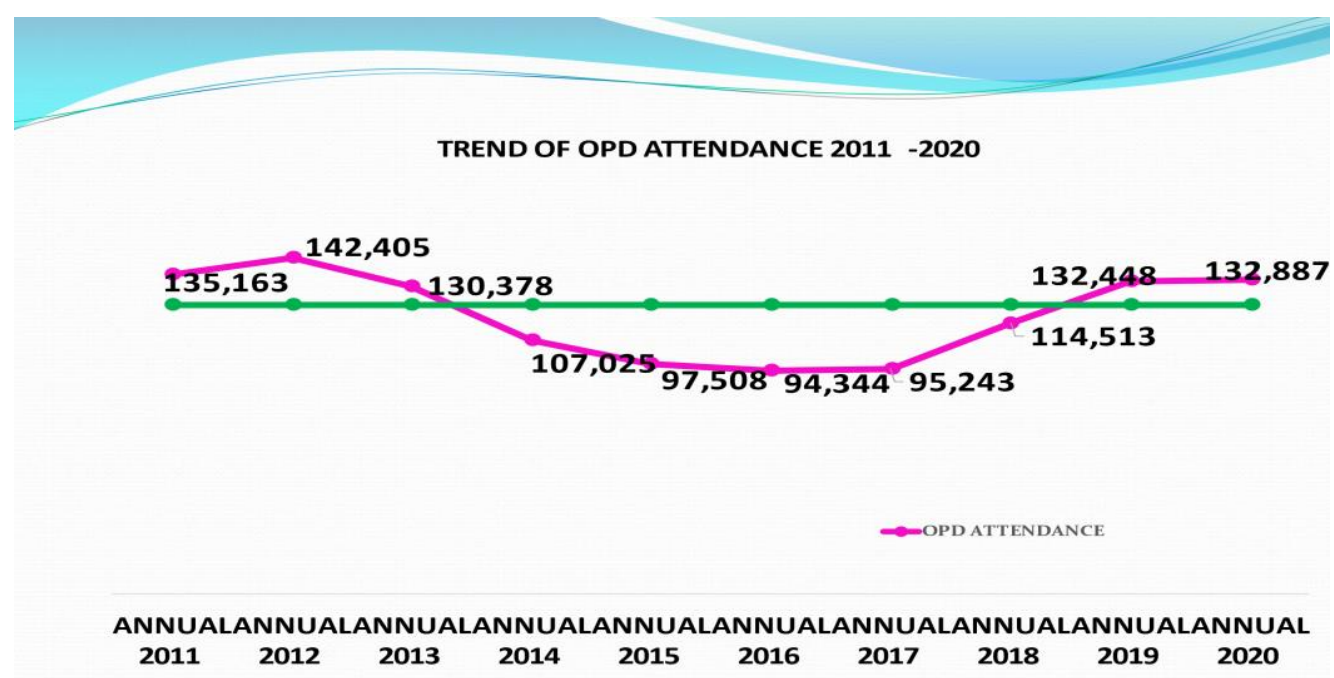

Source: Fieldwork, 2021

Figure 2. Trend of OPD Attendance 
Advance healthcare revenue practice Ultimately, the percentage of OPD insured management services write on its website that, among other things, it specializes in hospitalwide revenue mobilization, which enables hospitals to collect maximum reimbursements for the services rendered to their patients. It is when people visit the hospital with an insurance membership cards that reimbursement can be made. Health insurance reimbursement obviously is a measure of revenue mobilization. (figure 3) measures good medical outcomes since ordinarily, people will not visit the hospital where they were not sure of receiving quality care. Patients visit hospitals where they feel comfortable and were sure of receiving the best of care. This as a measure of medical outcomes was progressively on the rise during the year under review, about $89 \%$ of those who visited the mission hospitals were NHIS card bearers.

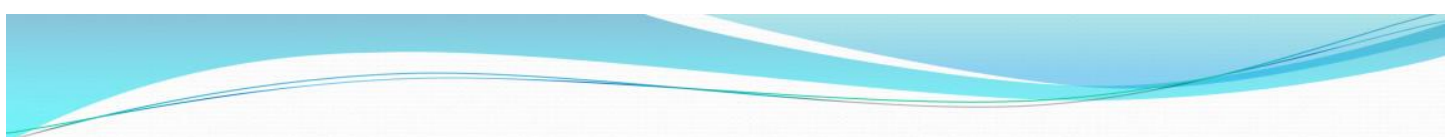

PERCENTAGE OPD INSURED 20112020

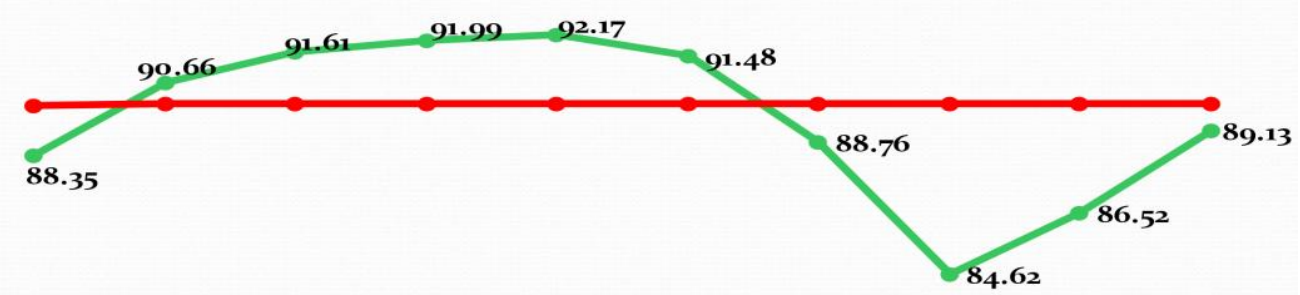

ANNUAL ANNUAL ANNUAL ANNUAL ANNUAL ANNUAL ANNUAL ANNUAL ANNUAL ANNUAL

$\begin{array}{llllllllll}2011 & 2012 & 2013 & 2014 & 2015 & 2016 & 2017 & 2018 & 2019 & 2020\end{array}$

Source: Fieldwork, 2021

\section{Conclusion}

The investigator was right by his assumption that financial health affects the medical outcomes of the hospital. From the above data and subsequent discussions, it came out clearly that the financial health of the hospitals had

Figure 3. Trend of Percentage OPD Insured

Table 4. Financial Health Indicators

\begin{tabular}{|l|l|l|l|}
\hline Parameters/Ratios & $\mathbf{2 0 1 8}$ & $\mathbf{2 0 1 9}$ & $\mathbf{2 0 2 0}$ \\
\hline Profitability Ratios & 2.79 & 7.32 & 5.25 \\
\hline Return on Capital Employed (ROCE) & 1.72 & 4.59 & 3.10 \\
\hline Net Profit Margin & 1.62 & 1.59 & 1.69 \\
\hline Asset Turnover Ratio & 2.35 & 2.48 & 3.41 \\
\hline Liquidity Ratios & 1.73 & 1.98 & 2.66 \\
\hline Current Ratio & &
\end{tabular}




\begin{tabular}{|l|l|l|l|} 
Working Capital Management Ratios \\
\hline Receivables Days Ratio (Average Receivables Collection Period) & 83.56 & 87.09 & 74.62 \\
\hline Payables Days Ratio (Average payables payment period) & 237.98 & 242.81 & 194.03 \\
\hline Average Inventory Turnover Period & 176.09 & 128.26 & 115.18 \\
\hline Rate of Inventory Turnover & 2.07 & 2.85 & 3.17 \\
\hline Cash Conversion Cycle & 21.67 & $(27.46)$ & $(4.23)$ \\
\hline
\end{tabular}

\section{Acknowledgment}

I would like to sincerely thank Professor Peter Agyei-Baffour for his guidance in this investigation. Also, I wish to thank Godwin Adzakpah and Richard Ahorlu, CA, for their inputs in this study.

\section{References}

[1] Henry Frimpong, (2017). An Anatomy of the Business and Financial Performance of State-Owned Financial Institutions in Ghana (2012-2015). Available at

https://www.texilajournal.com/management/article/1 569-an-anatomy-of and retrieved on 3/06/2021.

[2] Aberese-Ako \& co, 2018. Leadership style on two Ghanaian hospitals in a challenging environment. Health Policy and Planning, Volume 33, Issue suppl_2, July 2018, Pages ii16-ii26, https://doi.org/10.1093/heapol/czy038. Retrieved on 29/06/2021.

[3] George Schieber et al, (2012). World Bank Report: Health Financing in Ghana at Crossroads. Available at

https://openknowledge.worldbank.org/handle/10986/ 2729 and retrieved on 17/07/2021.

[4] John Kweku Asamoah, (2018). The Impact of Effective Leadership Practice on Organizational Performance and Growth of state-owned banks in Ghana: The Case of National Investment Bank, Ghana.

[5] Stella Cherono (2021). Kenyan Doctor wins WHO Director-General Award. Available at https://nation.africa/kenya/gender/kenyan-doctorwins-who-director-general-s-award--3414122 and retrieved on 09/06/21.

[6] World Health Report (2010). Health systems financing: the path to universal coverage. Geneva:

\section{Conflict of Interest}

The principal investigator declares that there is no conflict of interest.

World Health Organization; 2010. Available on https://www.who.int/bulletin/volumes/91/8/12-

113985/en/, and retrieved on 13/05/2021.

[7] World Health Report (2000). Health systems: improving performance. World Health Organization, Geneva, 2000 available at https://www.who.int/healthinfo/statistics/toolkit_hss/ EN_PDF_Toolkit_HSS_Financing.pdf and retrieved on $25 / 05 / 2021$.

[8] George Schieber et al, (2012). World Bank Report: Health Financing in Ghana at Crossroads. Available

at https://openknowledge.worldbank.org/handle/10986/ 2729 and retrieved on 17/07/2021.

[9] World Health Organization, (June 2008). Health Systems Financing. Available and retrieved on 20/05/2021

https://www.who.int/healthinfo/statistics/toolkit_hss/ EN_PDF_Toolkit_HSS_Financing.pdf.

[10] World Health Organization, (2021). Overview health financing. Available at https://www.who.int/health-topics/health-

financing\#tab=tab_1 and retrieved on 17/07/2021.

[11]Christmals CD, Aidam K, (2020). Implementation of the National Health Insurance Scheme (NHIS) in Ghana: Lessons for South Africa and Low- and Middle-Income Countries. Available at https://www.dovepress.com/implementation-of-thenational-health-insurance-scheme-nhis-in-ghana-1- 
peer-reviewed-fulltext-article-RMHP and retrieved on $22 / 05 / 2021$.

[12] Alanna-Moriarty (2011). Definitive healthcare Interactive dashboard with rich customization and self-service.

Available

at

https://www.datanyze.com/people/Alanna-

Moriarty/-1049632075.

[13] Wendy Gerhardt \& Ankit Arora (2020). Hospital revenue trends Outpatient, home, virtual, and other care settings are becoming more common. Retrieved on $10 / 08 / 2021$ and available at https://www2.deloitte.com/us/en/insights/industry/he alth-care/outpatient-virtual-health-care-trends.html. [14] Tyler Heist et at, (2021). Trends in overall and non-covid-19 hospital admissions. Retrieved on $12 / 08 / 2021$ and available at https://www.kff.org/health-costs/issue-brief/trendsin-overall-and-non-covid-19-hospital-admissions/.

[15]Nana Kwame Ayisi-Boateng et al (2020). Fighting the covid-19 pandemic in Ghana: a report from the Kwame Nkrumah University of Science and Technology, Kumasi. Retrieved on 20/07/2021 at Doi: 10.11604/pamj.supp.2020.37.43.25749.

[16] George Schieber, Cheryl Cashin, Karima Saleh, Rouselle Lavado (2012). Health financing in Ghana. World Bank Publications.

[17] NHIS, (2021). NHIS Review. Terms of reference for defining options for national health insurance scheme reforms. Retrieved on 02/07/2021 and available at http://www.nhis.gov.gh/nhisreview.aspx. [18] World Health Organization, World Bank, (2015). Tracking universal health coverage: first global monitoring report. Retrieved on 17/07/2021 and available

at www.who.int/healthinfo/universal_health_coverage/ report/2015/en.

[19]Helleiner, G. K., (1983). “Accelerated development in sub-Saharan Africa, an agenda for action: The World Bank, (Washington, 1981) viii + 198 pp," Journal of Development Economics, Elsevier, vol. 13(1-2), pages 259-264.

[20]Fallon E. Chipidza et al, (2015). Impact of the doctor-patient relationship. Retrieved on 22/07/2021. Published online 2015 Oct 22. Doi: 10.4088/PCC.15f01840.
[21]Ezat Wan Puteh S, Almualm Y. (2017). Catastrophic health expenditure among developing countries. Health Syst Policy Res. 2017;4. DOI:10.21767/2254-9137.100069.

[22] Tod Beasley (2020). How to gauge your hospital's financial health. Available at https://www.beckershospitalreview.com/how-togauge-your-hospital-s-financial-health.html and retrieved on 20/07/2021.

[23] Paul D. Cleary (1990). Using patient reports of outcomes to assess the effectiveness of medical care. Available at https://www.ncbi.nlm.nih.gov/books/NBK233993/ and retrieved on 21/07/2021.

[24] Sara Heath, 2020, How Will COVID-19 Change Patient Experience, Healthcare Delivery? at https://patientengagementhit.com/news/how-willcovid-19-change-patient-experience-healthcaredelivery, retrieved on 10/07/2021.

[25] Osondu Ogbuoji et all (2019). Closing Africa's health financing gap available at https://www.brookings.edu/blog/futuredevelopment/2019/03/01/closing-africas-healthfinancing-gap/ and retrieved on 09/07/2021.

[26]IBM health forum (2021). Healthcare performance measurements. Retrieved on 20/07/2021 and available at https://www.ibm.com/watsonhealth/learn/healthcare-performance-measurements.

[27] Ryan, T. P. (2013). Sample size determination and power, John Wiley \& Sons.

[28]Bryman, A, \& Bell, Emma, (2007). Business Research Methods. Oxford University Press.

[29] Amitava Dasgupta Jorge Sepulveda, (2013). Accurate results in the clinical laboratory. A guide to error detection and correction. Elsevier, Waltham, MA, USA.

[30] Audited Financial Statements (2018, 2019 \& 2020).

[31] Advance healthcare revenue practice management services (2021). Revenue management services. Retrieved on 15/08/2021 and available at https://www.ahrevenue.com/?gclid=CjwKCAjwx8iI BhBwEiwA2quaq6Lod8PMLtqYO8jHS1NFWGeru E9SVUC3smnG5mmNuwtubgk2aMJ9rhoCUpYQA vD_BwE. 
[32]T. N. Akudjedu et al. (2021). Impact of the Covid-19 pandemic on clinical radiography practice in low resource settings: The Ghanaian radiographers' perspective. Retrieved on 20/07/2021 at PMID: 33168371. DOI:

10.1016/j.radi.2020.10.013. 